\title{
Rasm Mushaf Usmany Dan Rahasianya (Sebuah kajian tentang bukti baru kemu'jizatan Al-Qur'an)
}

\author{
Abdul Aziz
}

Penulis adalah Dosen UIN Malang

\section{ABSTRACT}

Syalabi wrote in his book that Abu Bakar has collected Al-Qur'an comprising seven readings which are allowed to be read. He did not specify on one certain reading. A lot of his friends also had their own mushaf. The differences, then, caused the different reading among Iraq and Syam society. This dispute made Khudzaifah bin al-Yaman was angry. He informed it to Usman bin Affan r.a. and finally Usman united the people in one letter or one reading and rasm.

\section{Pendahulan}

Al-Qur'an turun kepada Nabi Muhammad SAW pada saat kondisi baca tulis di dunia arab sedang langka. Bahkan sampai pada saat al-Qur'an ditulis, tulisan itu belum sempurna sebagaimana yang ada pada tulisan bahasa Arab sekarang. Al-Qur'an saat itu ditulis dengan tanpa titik dan tanpa harakat. Sehingga keterbatasan model tulisan Arab tersebut seringkali menjadi senjata para orientalis untuk

Ulul Albab, Vol. 4 No. 1, 2003 
melemahkan al-Qur'an dan Islam. Dalam makalah berikut insya Allah akan kita bahas secara singkat.

Al-Qur'an baru dibukukan beberapa tahun kemudian setelah pada perang Yamamah banyak panghafal al-Qur' an yang meninggal dalam peperangan tersebut. Kondisi ini banyak meresahkan para sahabat, karena umat Islam sering terlibat peperangan. Dan setiap peperangan selalu banyak menggugurkan para sahabat. Kegelisahan itu sangat dirasakan terutama oleh Umar bin Khaththab. Dan atas usulan beliau akhirnya al-Qur'an ditulis pada masa khalifah Abu Bakar r.a.

Syalabi' menulis dalam bukunya bahwa Abu Bakar telah menghimpun alQur'an mencakup tujuh huruf (baca: tujuh bacaan) yang telah diperbolehkan untuk dibaca, beliau tidak mengkhususkan satu bacaan tertentu. Kemudian banyak sahabat juga memiliki mushaf, seperti Umar bin Khaththab, Ali bin Abi Thalib, Ubay bin Ka'ab, Abdullah bin Mas'ud dan Ibnu Abbas, demikian juga para istri Nabi seperti: Aisyah, Hafshah, Umi Salamah. Ada juga para tabi' in seperti 'Atho' bin Rabah, Ikrimah, dan Mujahid. Mushaf-mushaf tersebut sanadnya shahih, bacaannya tsiqah dan sesuai dengan bahasa arab, tetapi beberapa mushaf berbeda dengan yang lain. Kemudian perbedaan tersebut menyebabkan persengketaan bacaan di antara penduduk Iraq dan Syam. Dan persengketaan ini membuat Khudzaifah bin al Yaman marah hingga wajahnya memerah. Kemudian Khudzaifah bin al Yaman mengadukan kepada Utsman bin Affan r.a. kemudian Utsman menyatukan umat dalam satu huruf atau satu bacaan dan satu rasm, yang dikenal dengan rasm. Rasm pada mushaf itu tanpa titik dan syakal. Kemudian beberapa mushaf dikirim ke mesir dan memerintahkan kepada masing-masing daerah untuk mentashih mushaf-mushaf mereka berdasarkan mushaf yang dikirim dari Utsman tersebut. Demikian juga daerah-daerah yang lain bacaannya mengikuti mushaf utsman. Dan Utsman melarang bacaan yang tidak sesuai dengan bacaannya. Kemudian para ulama sepakat bahwa bacaan yang tidak sesuai dengan bacaan mushaf tersebut dianggap bid'ah dan salah, meskipun riwayatnya shahih.

Mushaf dengan rasm inilah yang telah disepakati oleh umat Islam, bisa diterima dengan urutan susunan ayatnya, bahkan urutan kalimat dan huruf-hurufnya, tidak ada alasan bagi kita untuk mengingkarinya. Mushaf utsman itu menjadi Imam dan dalil atau petunjuk urutan yang tidak boleh ada yang didahulukan atau diakhirkan, tidak boleh dikurangi atau ditambah, dan lafadznya tidak boleh diganti. ${ }^{2}$ 
Uraian berikut akan menggambarkan sekilas tentang Rasm Mushaf Usmani, temuan dan kesimpulan Goldzihr seputar qiraat serta bagaimana kita menyikapinya, rasm Mushaf Usmani dan bagaimana memperlakukan dan memeliharanya, ciriciri khusus rasm Mushaf Usmani dan contohnya serta rahasia di balik rasm Mushaf Usmani.

\section{Definisi Rasm Mushaf Usmani}

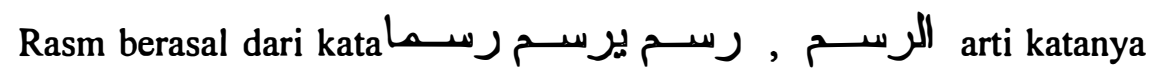
adalah الالثــر yang artinya bekas, jejak, goresan, pengaruh ${ }^{3}$, bisa juga berarti malukis, menggambar, menulis, membuat tanda artinya pengaruh tulisan dalam lafadz, menulis buku, membuat tanda tulisan $\mathrm{dll}^{4}$ yaitu Menggambarkan suatu kalimat dengan huruf-huruf hija'iyah, dimulai dan diakhiri dengan huruf-huruf tersebut. ${ }^{5}$ Sedangkan yang dimaksud dengan mushaf di sini adalah mushaf-mushaf yang telah ditulispada masa Khalifah Utsman yang telah disepakati oleh para sahabat meliputi urutan surat, ayat dan tata letaknya.

\section{Goldzihr dan Qira'at}

Goldzihr menulis dalam bukunya, Madzahibu al Tafsir al Islami, bahwa karena tulisan arab yang digunakan untuk menulis mushaf tidak disertai titik dan syakal atau harakat, itu menyebabkan adanya perbedaan dalam bacaan, dan perbedaan bacaan itu telah menyebabkan perbedaan tata bahasa dan juga perbedaan makna. $^{6}$

Dalam al Madzahibu al Tafsir al Islami, Goldzihr menyebutkan juga bahwa sebab terbesar dalam adanya perbedaan qira'at ini adalah karena ciri khas dalam penulisan arab, satu rasm atau satu tulisan bisa dibaca dengan bacaan yang berbeda, berdasarkan titik di bawa atau di atas tulisan, juga adanya harakat yang berbedabeda yang berimplikasi pada perbedaan kedudukan dalam tata bahasanya, yang kemudian pasti berdampak pada perbedaan arti. Lebih jauh dia menemukan perbedaan bacaan di dalam rasm mushaf itu karena dua sebab utama, yaitu:

Ulul Albab, Vol. 4 No. 1, 2003 
1. Mushaf itu tidak bertitik

2. Tidak adanya harakat nahwu atau syakal dalam tulisan arab, misalnya:

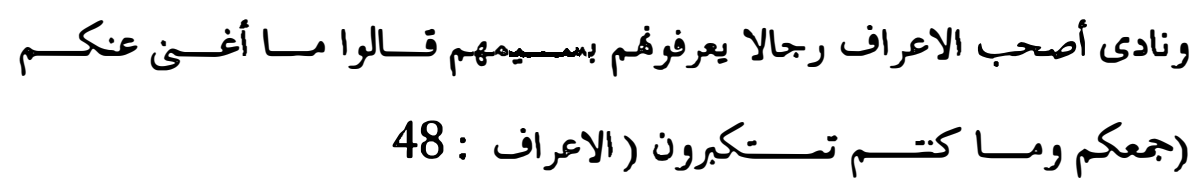

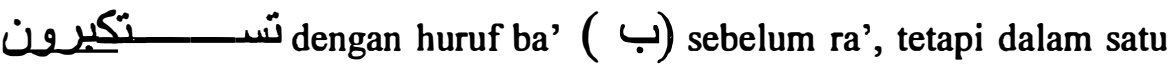

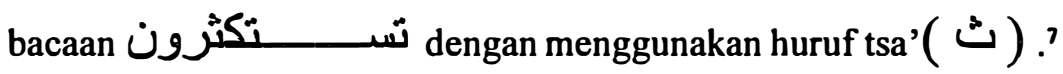

Untuk diketahui bahwa penulisan titik dan syakal (harakat) dimulai pada masa Ziyad, Gubernur Basrah, setelah Abul Aswad Al Duali mendengar seseorang membaca surat al Taubah, ayat 3:

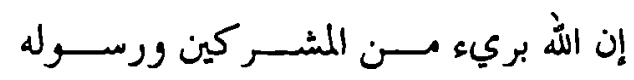

dalam ayat tersebut yang seharusnya dibaca rafa' (dhammah) orang itu membaca jar (kasrah), sehingga menimbulkan arti yang jauh berbeda. Kemudian Abul Aswad Al Duali mengusulkan kepada gubernur Ziyad untuk diberikan tanda baca pada al Qur'an tersebut. Dan dilanjutkan oleh murid-muridnya, di antaranya adalah Khalil bin Ahmad. (1986:458). Hal itu terjadi setelah kaum muslimin banyak berinteraksi dengan bangsa lain sehingga bahasanyapun banya bergesekan dengan bahasa-bahasa Ajam.

Untuk membantah tuduhan tersebut, Syalabi menyebutkan ada bukti-bukti secara historis dan berdasarkan periwayatan, sebagai berikut:

Pertama, sesungguhnya kalau perbedaan itu disebabkan oleh tulisan arab yang tidak bertitik dan bersyakal/berharakat, maka itu adalah pendapat yang salah dan tidak mendasar. Bukankah bacaan al-Qur'an itu diriwayatkan dan disebarkan terlebih dahulu sebelum dibukukan? Bukankah kita melihat bagaimana mereka 
meneliti, mencari-cari kekurangan dan kemudian menetapkannya? Dan bukankah al-Qur'an itu terlebih dulu terjaga dalam hafalan para sahabat jauh sebelum terbukukan?

Kedua,-mereka membedah al-Qur'an sebagaimana tulisan-tulisan lain orang arab, baik berupa syiir atau prosa. Maka jelas kalau begitu, mengapa tidak prosa dan syiir yang mereka riwayatkan? Padahal para penulis prosa itu, mereka adalah para tokoh dan pemimpin arab.

Ketiga, Jika bacaan itu mengikuti rasm usmani seperti yang dituduhkan Goldzihr, niscaya semua bacaan yang terkandung di dalam rasm mushaf itu benar. Padahal kenyataannya sebaliknya, beberapa bacaan yang dikandung dalam rasm mushaf itu benar dan beberapa ditolak. ${ }^{8}$

Keempat, Ada paradigma yang berbeda di dalam menyikapi proses turunnya al-Qur'an sampai pembukuannya antara kaum muslimin dengan para outsider yang mendalami Islam termasuk di dalamnya Goldzihr. Kaum muslimin mendasarkan kepada paradigma hafalan dulu kemudian tulisan. Jadi setelah al Qur'an turun. Nabi langsung membacakan kepada para sahabat untuk langsung dihafal terlebih dahulu, kemudian baru beliau memerintahkan untukditulis. Sedangkan mereka para outsider menggunakan paradigma tulisan saja, dan menafikan hafalan bahkan mereka juga tidak mengakui proses penukilan atau periwayatan yang sudah menjadi tradisi orang arab bahkan sebelum datangnya Islam.

Kelima, Periwayatan al Qur'an itu semuanya secara mutawatir, sehingga logika mengatakan tidak mungkin kalau munculnya beberapa qira'at itu disebabkan karena tulisan rasm mushaf Usmany yang tanpa titik dan syakal. Sebaliknya semakin menguatkan bahwa tidak mungkin para sahabat meriwayatkan bacaan yang tidak diterima dari Nabi Muhammad SAW.

\section{Rasm Usmani dan Bagaimana memperlakukannya}

Jumhur ulama berpendapat bahwasanya rasm mushaf yang ditulis oleh Zaid bin Tsabit, penulis wahyu, pada zaman Usman bin Affan adalah taugify tidak boleh ada tulisan dan cetakan yang menyalahi mushaf. Hal itu dikarenakan:

Ulul Albab, Vol. 4 No. 1, 2003 
1. Al-Qur'an tertulis semuanya pada masa Rasulullah SAW, dan beliau sendiri yang mendiktekan kepada penulis wahyu dan menunjukkan tulisannya berdasarkan wahyu dari Jibril a s .

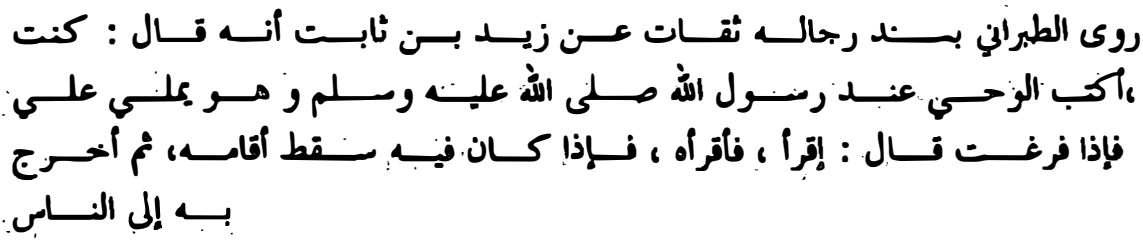

2. Kesepakatan semua qurra' terhadap kaidah-kaidah rasm mushaf yang didasarkan pada kesepakatan semua sahabat untuk mengikutinya dan tidak boleh berbeda dengannya. Karena rasm mushaf itu bersifat tauqify dari Rasulụllah sesuai teks al-Qur'an al-Karim. Imam Ahmad berkata:

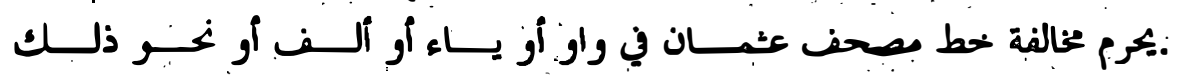

Al Baihaqy dalam Sya'b al Iman berkata: Barang siapa menulis mushaf maka hendaknya penulisan huruf hijaiyahnya seperti yang telah ditulis pada mushaf itu, tidak boleh menyalahinya, tidak boleh merubah sedikitpun dari apa yang telah mereka tulis, karena mereka lebih alim, hati dan lisannya lebih benar, lebih amanah, maka hendaknya kita tidak inenduga kita lebih tahu dari pada mereka.

3. Para ahli baca al-Qur'an semuanya sepakat bahwasanya Rasm Mushaf Usmany mengandung bacaan-bacaan yang periwayatannya mutawatir dari Rasulullah, karena itu ulama ushul mensyaratkan dalam qiraat yang mutawatir itu harus sesuai dengan rasm Usmany.

4. Jika saja rasm Usmani itu tidak bersifat tauqify dari Rasulullah, dan Rasulullah dari Jibril dan Jibril dari Allah, niscaya mushaf itu bersifat taqriry atau berdasarkan ketetapan Nabi, maka hal itu secara syara' tidak mendasar, karena Rasulullah sendiri yang membimbing penulisan Mushaf oleh Zaid bin Tsabit. ${ }^{9}$

\section{Ciri-Ciri Khusus Rasm Usmany}

Secara garis besar ciri-ciri khusus rasm usmany seperti ditulis oleh Al Suyuthi (911H: 328-337) adalah sbb: 
1. Tertib urutan ayat-ayatnya, dan surat-suratnya yang bersifat tauqify dari Rasulullah SAW dari Jibril dari Allah SWT.

2. Memiliki ciri khusus 7 kaidah rasm, yaitu:

a. Membuang huruf(الحذف) seperti alif setelah ya' nida' dan lainnya seperti :

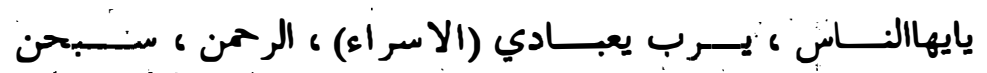

b. Menambah huruf (الز يادة) ) seperti huruf alif setelah huruf wawu, seperti :

$$
\text { (أولوا ألالبِّـابـ، الـــربوا! (الل عمران: } 7
$$

c. Penulisan huruf hamzah( الممزة) seperti penulisan huruf hamzah sukun atau mati, yang seharusnya huruf tersebut adalah huruf berharakat atau hidup, dsb:

$$
49 \text { : ائذن (التوبــــــــــ }
$$

d. Pertukaran huruf ( البــــ ) seperti penulisan wawu pada huruf alif,

$$
\text { الصلوة ، البـزز كوة }
$$

e. Penulisan dua kalimat yang dipisah (الفهـــل ) di beberapa tempat, seperti:

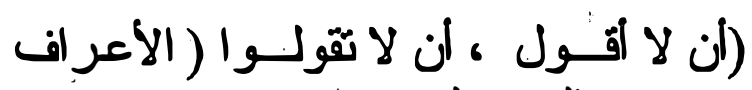

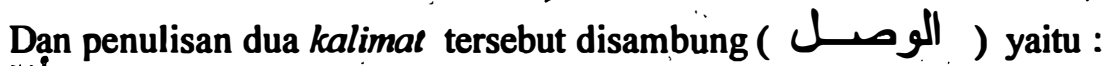
لا

f. Satu tulisan memiliki dua bacaan, seperti :

huruf mim bisa dibaca panjang dua harakat ( mad thobi'iy ) dan juga bisa dibaca pendek satu harakat, demikian juga يخــــــ dan masih banyak lagi.

3. Mengandung semua segi bacaan-bacaan yang mutawatir dari Nabi SAW.

4. Mengandung rahasia-rahasia turunnya ayat, misalnya: firman Allah dalam surat al Dzariyat: 47:



Huruf ya dua, tambahan huruf ya itu menunjukkan tanda kekuasaan dzat Pencipta yang telah membangun langit, dan tidak ada kekuatan apapun yang 
menyamainya, berdasarkan kaidah:

زيادة المبــنى تــــل علـــى زيـــادة المعــنى .10

\section{Rahasia Rasm Usmany dan Kémukjizatan Al-Qur'an}

Banyak hasil penelitian yang dilakukan terhadap Al-Qur'an yang semakin menambah nilai kemukjizatan Al-Qur'an. Di antaranya adalah hasil penelitian yang pernah dilakukan oleh Dr. Rusyad Kholifah, terhadap material tulisan al Qur'an rasm mushaf Usinany, di antaranya: penulisan basmallah dalam surat al Fatihah dengan tulisan (بـــ tanpa alif, bukan ( باســـ ) sebagaimana seharusnya

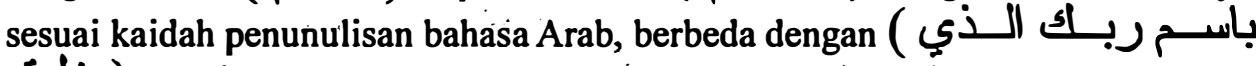
bisnirabbika alladzi khalaqa pada surat al Alaq; setelah diteliti bahwa

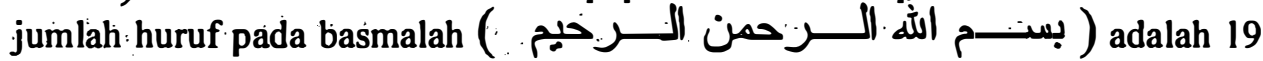
huruf. Setelah diteliti, ditemukan bahwa setiap kata di dalam basmalah tersebut, terulang-ulang dalam jumlah bilangan yang selalu merupakan hasil perkalian dengan angka 19. Misalnya: kata-kata yang terdapat dalam basmalah, di dalam Al-Qur'an disebutkan sebanyak 19 kali atau kelipatan 19. Rinciannya sebagai berikut:

1. Kata "Ismun" (إبـم ) di dalam Al-Qur'an terulang persis sebanyak 19 kali.

2. Kata “Allah" : (الذ) ) di dalam Al-Qur'an terulang sebanyak 2.698 kali, dimana bilangan tersebut merupakan kelipatan $19 \times 142$.

3. Kata "Al-Rahman" (الرحن) ) di dalam Al-Qur'an terulang sebanyak 57 kali, merupakan hasil perkalian angka $19 \times 3$.

4. Kata "Al-Rahim" ( الكرحيم ) di dalam Al-Qur'an terulang sebanyak 114 kali; merupakan kelipatan angka $19 \times 6 .{ }^{i 1}$

Barangkali ada saja yang mengatakan kalau angka-angka tersebut kebetulan, tetapi seandainya basmalah ditulis tidak dengan rasm mushaf Usmani, misalnya

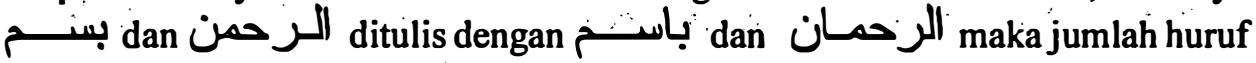
pada basmalah tersebut tidak 19, tetapi 21, maka jumlah tersebut tidak sama dengan jumlah kata-kata basmalah yang terulang dalam Al-Qur'an sebagaimana telah kami tulis di depan.

Al-Qur'an sama dengan kata/kalimat الـرحن , الاسـم , الــ , dan masing-masing jumlahnya kelipatan 19 'dan masih banyak lagi rahasia- 
rahasia di balik penulisan rasm mushaf Usmany, yang akan bisa ditemukan jika kita mau melakukan penelitian dan kajian mendalam.

Dr. Rusyad Khalifah juga menyebutkan, ${ }^{12}$ setelah diteliti lebih lanjut, hurufhuruf dalam basmalah yang berjumlah 19 huruf itu, 14 huruf merupakan huruf pembuka surat-surat di dalam Al-Qur'an. Huruf-huruf pembuka itu terdapat di 29 surat. Penjelasan masing-masing huruf pembuka tersebut sebagai berikut:

1. Huruf Qaf ( $)$

Huruf ini menjadi pembuka di dua surat, yaitu surat Qaf dan surah Asy-Syura.

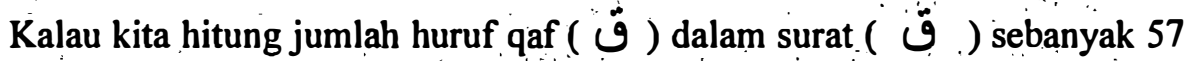
huruf, jumlah ini merupakan kelipatan angka $19 \times 3$.

Demikian juga jumlah huruf ( $)$ dalam surah Asy-Syura, setelah di hitung jumlahnya sama dengan jumlah huruf qaf (ق) di dalam surah (ن) yaitu 57 huruf (ن). Jumlah ini adalah kelipatan angka 19 × 3, meskipun surah AsySyura lebih panjang dari pada surah Qaf.

Jumlah kedua surah yang dibuka dengan huruf Qaf ( $)$ ) secara matematis adalah

$56+56=114$, bilangan ini adalah jumlah surah di dalam Al-Qur'an. Bila setiap huruf qaf ( ) dirumuskan sebagai isyarat untuk kata "Qur'an"( ( maka adalah sangat mungkin sekali, dan itu berarti bahwa sesungguhnya angka 114 tersebut, itulah jumlah semua surah-surah dalam AlQur'an, bukan yang lain.

2. Huruf shad ( ص)

Hurufini merupakan pembuka 3 buah surah di dalam Al-Qur'an, yaitu berada dalam surah Al-A'raf berbunyi ( الدص. ), surah Maryam berbunyi (.

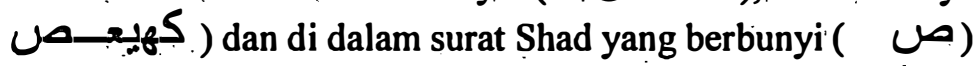

Kalau semua huruf ( ص) yang ada di ketiga surah yang diawali dengan huruf ( ص) tersebut dijumlah maka seluruhnya sebanyak 152 huruf. Jumlah ini merupakan kelipatan angka $19 \times 8$.

Kalau diteliti setiap huruf ( ص), akan dijumpai ada satu kata yang terdiri dari huruf ( ص) di dalam surat Al-A'raf ayat 69, yaitu ( بصــــ ), bukan

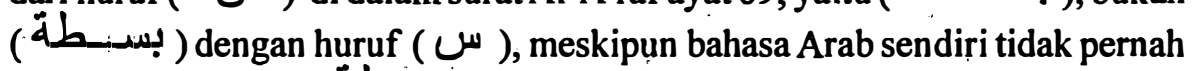

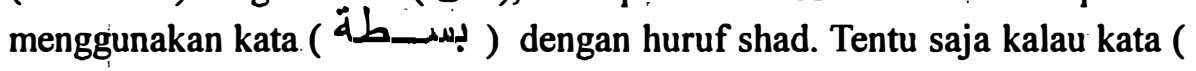




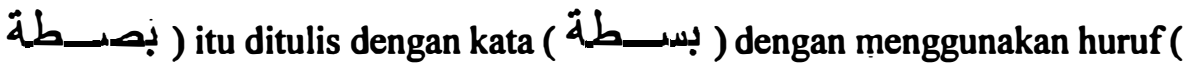
س ) maka jumlah huruf ( ص a) pada ketiga surah yang diawali dengan huruf ( ص ) akan menjadi 151, suatu angka yang bukan kelipatan 19.

3. Dan huruf-huruf pembuka surah yang lain seperti huruf Alif ( 1 ) dan huruf Lam (ل), jumlah huruf tersebut di dalam Al-Qur'an merupakan kelipatan 19, huruf Mim ( $r$ ), jumlah huruf mim pada surah-surah yang dibuka dengan huruf itu merupakan kelipatan angka 19. Demikian juga huruf $(b)$ dan $(ه)$ dalam surah Thaha, berjumlah 342 huruf, merupakan kelipatan 19 x 18, dan huruf (ي) dan ( $(M)$ dalam surah Yasin jumlah masing-masing huruf pembuka tersebut di dalam Al-Qur'an merupakan kelipatan 19. Juga huruf ha' $\left(乙^{\prime}\right)$ dan huruf Mim ( $P$ ) dalam tujuh surah, jika dijumlahkan masing-masing huruf tersebut, maka hasilnya merupakan kelipatan 19.

\section{Kesimpulan dan Analisa}

1. Rasm Mushaf Usmani adalah mushaf-mushaf yang telah ditulis pada masa Khalifah Utsman yang telah disepakati oleh para sahabat dan para ulama meliputi urutan surat, ayat dan sebagainya.

2. Pendapat yang dikemukakan oleh Goldzihr bahwa adanya perbedaan qiraat itu disebabkan karena tulisan arab yang digunakan untuk menulis mushaf pada masa Usman belum sesempurna sekarang (tanpa titik dan harakat, sehingga secara tersirat ia menuduhkan bahwa bacaan al-qur'an itu kebenarannya patut diragukan. Akan tetapi kita bisa membantah bahwa al-Qur'an itu ditulis setelah Nabi membacakan kepada para sahabat kemudian para sahabat segera menghafalnya. Jadi tidak benar kalau bacaan itu didasarkan kepada tulisan, justru sebaliknya tulisan itu hanya berfungsi untuk mengikat hafalan yang telah melekat di otak para sahabat.

3. Ada paradigma yang berbeda antara kaum muslimin dengan outsider. Kaum muslimin mendasarkan kepada paradigma hafalan dulu kemudian tulisan yang didasarkan pada sejarah turunnya dan periwayatan al Qur'an. Sedangkan outsider menggunakan paradigma tulisan saja, dan menafikan hafalan bahkan mereka juga tidak mengakui periwayatan, padahal orang arab mempunyai 
kelebihan dalam hal tradisi hafalan. Hal itu semakin dibuktikan dengan adanya kemutawatiran periwayatan al Qur'an yang tidak bisa dibantah oleh logika.

4. Dengan demikian kita semakin yakin bahwa bacaan dari tulisan al-Qur'an itu bersifat tauqify dari Nabi SAW, dari malaikat Jibril a.s., dari Allah SWT. Jadi bukan buatan Muhammad SAW, apalagi para sahabat: Terlebih Allah telah menjamin dalam firmannya:

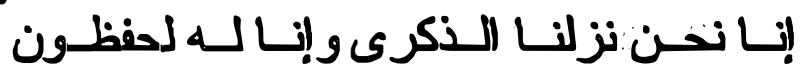

5. Karena rasm mushaf usmani itu bersifat tauqify, maka semua ulama sepakat menjadikannya sebagai rujukan bacaan, baik dalam urutan surat dan ayatnya, kalimat dan hurufnya, bahkan taqdim dan ta'khirnya. Dan sebagian besar ulama mewajibkan penulisan al-Qur'an harus sesuai dengan rasm mushaf Usmany, meskipun tidak sesuai dengan kaidah nahwu.

6. Di balik turunnya al-Qur'an yang bersifat "tauqify" sampai tata cara penulisannya ternyata jika dilakukan penelitian, ada temuan-temuan yang semakin menunjukkan kebesaran mu'jizat al-Qur'an. Seperti yang telah dilakukan oleh Dr. Rasyad Khalifah, 19 angka spektakuler sebagai angka jumlah huruf basmalah, dan masing-masing kata الـرجن ; اسبـ , dan di dalam al-Qur'an disebutkan sebanyak kelipatan 19 kali. Dan masih banyak lagi rahasia di dalam al-Qur'an dengan keajaiban angka 19 tersebut. Dan tentu angka-angka tersebut bukanlah karena kebetulan apalagi karena dibuat-buat oleh Nabi Muhammad atau oleh pengikut Nabi Muhammad-seperti yang dituduhkan oleh para outsider- sebab al-Qur'an turun secara bertahap, surat demi surat, bahkan ayat demi ayat, selama 22 tahun lebih. Tetapi temuan tentang angka-angka tersebut merupakan bukti kebesaran Allah yang menciptakan keajaiban keagungan firman-Nya. Wallahu A'lamu bi al Shawab

\section{Endnotes}

Dr. Abdúl Fattah Ismail Syalabi, Rasm al Mushaf al Utsmani, Dar al Manarah, Jiddah, $1990 \mathrm{M}-1410 \mathrm{H}$, hal. $10-11$

Ulul Albab, Vol. 4 No. 1, 2003 
2 Dr. Abdul Fattah Ismail Syalabi, Op. Cit., hal. 12

3 Atabik Ali, Kamus Kontemporer Arab-Indonesia, Cet. Keempat, Yogyakarta, : Multi Karya Grafika, 1996, hal. 22

4 Ibid., hal. 970

3. Dr. Abdul Fattah Ismail Syalabi, Op. Cit., hal. 9

$6 \quad$ Ibid, hal.5

7 Ibid, hal.18

- Ibid, hal.23-33

- Kholid Abdurrahman Al-Ak, Ushul al Tafsir wa Qawa'iduhu, Dar al Nakhois, Cetakan kadua, 1986 M, hal.451-452

10 Abd Rahman bin Abi Bakar al Suyuthi al Syafi'I, Al Itgan fi Ulum al Qur 'an, Juz II, Dar al Kutub al Ilmiyah, Beinut, hal. 328-337

i) Dr. Rusyad Kholifah, 19 Bukti Baru Mu'jizat Al-qur'an,Diterjemahkan oleh M. Anas Adnan, Penerbit Alfinik Surabaya, 1995, hal. 11-12

12 Ibid, hal. 26-32

\section{Bibliografi}

Dr: Abdul Fattah Ismail Syalabi, Rasm al Mushaf al Utsmani, Dar al Manarah, Jiddah, $1990 \mathrm{M}-1410 \mathrm{H}$

Imam Ibn Khalawih, Syarah: Dr. Abdul 'Ali Salim Mukarram, Al Hujjah fi al Qira'at al Sab'I, Dar al Syuruq, Kuwait

Al Imam Jalal al Din Abd Rahman bin Abi Bakar al Suyuthi al Syafi'I, Al Itgan $f i$ Ulum al Qur 'an, Juz II, Dar al Kutub al Ilmiyah, Beirut

Kholid Abdurrahman Al-Ak, Ushul al Tafsir wa Qawa'iduhu, Dar al Nakhois, Cetakan Kedua, 1986 M/1406 H

Atabik Ali, Kamus Kontemporer Arab-Indonesia, Cet. Keempat, Yogyakarta: Multi Karya Grafika, 1996.

Manna' al Qaththan, Mabahis fi Ulum al Qur 'an, Mansyurot al 'Ashri al Hadits, 1973

Dr. Rusyad Khalifah, 19 Bukti Baru Mukjizat Al-Qur 'an, Diterjemahkan oleh M. Anas Adnan, Penerbit “Alfinik Surabaya, 1995. 